\title{
Ecosystem Processes Show Uniform Sensitivity to Winter Soil Temperature Change Across a Gradient from Central to Cold Marginal Stands of a Major Temperate Forest Tree
}

\author{
Robert Weigel, ${ }^{1,2 *} \odot$ Hugh A. L. Henry, ${ }^{3} \odot$ Ilka Beil, ${ }^{1} \odot$ Gerhard Gebauer, ${ }^{4} \odot$ \\ Gerald Jurasinski, ${ }^{5} \odot$ Marcin Klisz, ${ }^{6} \odot$ Ernst van der Maaten, ${ }^{7} \odot$ \\ Lena Muffler, ${ }^{1,2} \odot$ and Juergen Kreyling ${ }^{1} \odot$
}

\begin{abstract}
${ }^{1}$ Experimental Plant Ecology, Institute of Botany and Landscape Ecology, University of Greifswald, 17489 Greifswald, Germany; ${ }^{2}$ Plant Ecology, Albrecht-von-Haller-Institute for Plant Sciences, University of Goettingen, 37077 Goettingen, Germany; ${ }^{3}$ Department of Biology, University of Western Ontario, London N6A 5B7, Canada; ${ }^{4}$ BayCEER - Laboratory of Isotope Biogeochemistry, University of Bayreuth, 95440 Bayreuth, Germany; ${ }^{5}$ Landscape Ecology, University of Rostock, 18059 Rostock, Germany; ${ }^{6}$ Department of Silviculture and Genetics of Forest Trees, Forest Research Institute, 05-090 Raszyn, Poland; ${ }^{7}$ Forest Growth and Woody Biomass Production, Institute of Forest Growth and Forest Computer Sciences, TU Dresden, 01737 Tharandt, Germany
\end{abstract}

\begin{abstract}
The magnitude and frequency of soil frost events might increase in northern temperate regions in response to climate warming due to reduced insulation caused by declining snow cover. In temperate deciduous forests, increased soil frost severity can hamper tree growth and increase the mortality of fine roots, soil fauna and microorganisms, thus altering carbon and nutrient cycling. From single-
\end{abstract}

Received 18 March 2020; accepted 28 December 2020; published online 28 January 2021

Supplementary Information: The online version contains supplementary material available at https://doi.org/10.1007/s10021-021-0060 $0-4$.

Authors Contributions R.W. and J.K. conceived and designed the study with contributions from G.G., G.J. and H.H. All authors contributed to data collection from field sampling to laboratory analysis. R.W. and J.K. discussed the wider implication of the study results with all other authors. R.W. led the writing together with J.K. and H.H. All authors contributed critically to the drafts and gave final approval for publication. *Corresponding author; e-mail: robert.weigel@uni-goettingen.de site studies, however, it is unclear how the sensitivities of these responses change along continental gradients from regions with low to high snowfall. We conducted a gradient design snow cover and soil temperature manipulation experiment across a range of lowland beech forest sites to assess the site-specific sensitivity of tree growth and biogeochemical cycling to soil cooling. Even mild and inconsistent soil frost affected tree increment, germination, litter decomposition and the retention of added ${ }^{15} \mathrm{~N}$. However, the sensitivity of response (treatment effect size per degree of warming or cooling) was not related to prevailing winter climate and snow cover conditions. Our results support that it may be valid to scale these responses to simulated winter climate change up from local studies to regional scales. This upscaling, however, needs to account for the fact that cold regions with historically high snowfall may experience increasingly harsh soil frost conditions, whereas in war- 
mer regions with historically low snowfall, soil frost may diminish. Thus, despite the uniform biotic sensitivity of response, there may be opposing directions of winter climate change effects on temperate forests along continental temperature gradients due to different trends of winter soil temperature.

Key words: European beech; forest ecology; frost sensitivity; global change ecology; gradient experiment; snow manipulation experiment; winter ecology.

\section{HighLights}

- Even mild soil frost affected tree growth and biogeochemical cycling

- The sensitivity of response was not related to prevailing winter climate

- Findings support scaling up from local studies to regional scales

\section{INTRODUCTION}

The magnitude of climate warming over the current century is projected to vary both regionally and seasonally. Warming is generally projected to increase with latitude, with mean rates of warming exceeding the global average by up to $50 \%$ in cool and cold temperate climates (IPCC 2013). For these regions, snowfall during winter is a typical feature and soils are protected from frost events if the snow cover remains sufficiently deep and continuous (Sturm and others 1997; Groffman and others 2001; Wipf and others 2009; Kreyling 2020). With rising mean winter air temperatures, the depth of this insulating snow cover will likely decline or snow cover will be absent during winter more often (McCabe and Wolock 2010; Kreyling and Henry 2011; Ye and Lau 2017; Reinmann and others 2019). However, frost events during winter may persist despite warmer mean winter air temperatures, and a future warming of the Polar Ocean might even increase the likelihood of winter cold events in Europe due to increased advection of polar air masses (Petoukhov and Semenov 2010; Yang and Christensen 2012). A more frequent absence of snow cover in combination with the occurrence of cold winter air temperatures is anticipated to result in the phenomenon of increased soil frost frequency and magnitude in some regions despite global warming (Groffman and others 2001; Kreyling 2020).

Soil frost events directly affect biogeochemical cycling and soil organisms during winter, and winter frost damage to fine roots can reduce nutrient uptake over the following growing season (Campbell and others 2014; Schuerings and others 2014; Reinmann and Templer 2016). This reduced nutrient uptake and delayed onset of tree growth due to soil frost may in turn reduce annual aboveground tree growth rates (Jyske and others 2012; Suvanto and others 2017; Sanders-DeMott and others 2018; Reinmann and others 2019). With respect to recruitment, seeds of temperate forest trees often require a stratification period (sufficient exposure to chilling temperatures) during winter, followed by a warm period to break seed dormancy and initiate germination (Walck and others 2011). Increased soil temperature variability resulting from discontinuous snow cover may increase the risk of frost damage for seeds due to premature breaking of seed dormancy (Hawkins and others 2003; Walck and others 2011). A shift in snow cover and soil frost regimes also could alter the relative abundances of forest understory plant species, with consequences for the timing of nutrient release and nutrient retention in the forest floor (Mabry and others 2007; Kreyling and others 2012).

Soil frost in winter, and the resulting disruption of microbial and faunal decomposer activity, can reduce decomposition rates in the following growing season (Yanai and others 2011; Bokhorst and others 2013; Kreyling and others 2013). In contrast, increased availability of fine root necromass due to soil frost can fuel decomposer activity and thus increase annual soil respiration in temperate forests (Matzner and Borken 2008; Reinmann and Templer 2018). Here, decreased root nutrient uptake during the growing season following winter frost exposition also can be a major cause of nitrogen leaching losses (Groffman and others 2001; Matzner and Borken 2008; Campbell and others 2014). In this plant-soil feedback loop, these changes to the soil nutrient cycle can influence plant growth; for example, the main rooting depth may shift to deeper soil layers to optimize nutrient capture (Schuerings and others 2013). Despite the complex interactions between biogeochemical and ecological processes in response to decreased soil temperatures, winter climate change studies often focus on single or only a few processes, either below- or aboveground (Makoto and others 2014), which precludes a more general understanding of these interactions. 
In temperate regions, snow cover can vary strongly along climatic gradients (Kreyling and Henry 2011; Makoto and others 2014), and within temperate sites, snow accumulation can vary widely with only small air temperature differences (Henry 2008; Brown and Mote 2009; McCabe and Wolock 2010). Therefore, the phenomenon of increased soil frost during winter despite global warming is expected to be most pronounced in cool temperate ecosystems, for which climate models consistently project declining snow cover despite increasing winter precipitation (Brown and Mote 2009; McCabe and Wolock 2010; Kreyling 2020). In contrast, snow cover in winter might persist or even increase in the future in higher-latitude regions with very cold climates, where flooding events and an increasing frequency of freeze-thaw cycles in spring might be more problematic due to faster snowmelt (Bulygina and others 2010; Iijima and others 2010; Kreyling 2020). Cool temperate ecosystems, however, have the potential to transition from winters with thick, consistent snow cover to those with only thin or discontinuous snow cover, while still frequently experiencing cold air temperatures (and thus intense soil frost) repeatedly at night or during cold spells (Falarz 2004; Brown and Mote 2009; McCabe and Wolock 2010; Makoto and others 2014). Conversely, soils in warm temperate regions that currently experience only sporadic snowfall and occasional soil frost events are projected to experience a future reduction in soil frost frequency and magnitude (Kreyling and Henry 2011). Due to potential local adaptation of plant and soil communities to past winter conditions, it has been hypothesized that frost tolerance and the sensitivity of ecosystem responses to altered soil temperatures during winter may be site specific (Makoto and others 2014; Reinmann and others 2019). Particularly, biota of cold temperate sites with historically regular snow cover may react stronger (that is, be more sensitive) to future winter climate change than sites with a history of irregular snow cover (Dionne and others 2001). If the responses of plants, soil biota and soil processes to variation in winter soil temperatures were site specific, then generalizing from findings of single-site studies and upscaling to the biome level would be problematic.

To test the assumption of site-specific sensitivity to winter climate change, we altered soil temperatures during winter in a snow manipulation experiment that was replicated along a large winter temperature gradient. Our study was explicitly aimed to analyze the ecological impacts of winter soil temperature variation corresponding to the range of realistic soil temperature scenarios encountered across the whole study gradient, instead of modelling in detail each site-specific future snow cover regime. Such a gradient design experiment requires that, apart from the investigated soil temperature differences, all other site conditions are kept as similar as possible. We therefore selected beech forests (Fagus sylvatica L.) in the European Pleistocene lowlands as a study system due to their geological, pedological and ecological uniformity across strong snowfall and winter temperature gradients (from irregular to more regular snow cover conditions, across $\Delta T=4 \mathrm{~K}$ over $500 \mathrm{~km}$ ), but with similar overall precipitation amounts. Beech naturally dominates in European temperate forests (Leuschner and others 2006), so that findings of our study area may be representative for large parts of the forest area in Europe. Moreover, this study contributes to a more general understanding of winter climate change impacts on plant growth and biogeochemical cycling in forest ecosystems by providing an assessment of responses and interactions of decomposition rates, soil respiration, nitrogen cycling, root growth dynamics, vegetation dynamics, forest tree seed germination and tree stem growth dynamics. We hypothesized that (1) soil cooling decreases plant growth and alters biogeochemical cycling and that (2) the highest sensitivity of response to altered soil temperatures occurs at the coldest sites, where soils have been protected historically from frost by an insulating layer of snow cover.

\section{Materials AND Methods}

\section{Study Area, Site Selection and Study Tree Selection}

We conducted this study in nine temperate deciduous forests (Figure 1) that are mono-dominated by mature European beech trees in an area with annual precipitation sums ranging $540-630 \mathrm{~mm}$ and mean annual air temperatures ranging 5.6$8.8^{\circ} \mathrm{C}$ (gridded climate data for the period 19611990, "climateEU" 4.63, Wang and others 2012; Hamann and others 2013). Along the 500-km study gradient, long-term average winter air temperatures decrease by $\Delta T=4 \mathrm{~K}$ (Figures 1, 2), which is a strong decrease compared to the climatic distribution range of beech (Figure 1C). The westernmost (warmest) sites have mean winter air temperatures above $0^{\circ} \mathrm{C}$, while those of the easternmost (coldest) sites are almost $-4^{\circ} \mathrm{C}$. The sites are evenly distributed along the temperature gradient (Figure 1C). From west to east, mean annual 

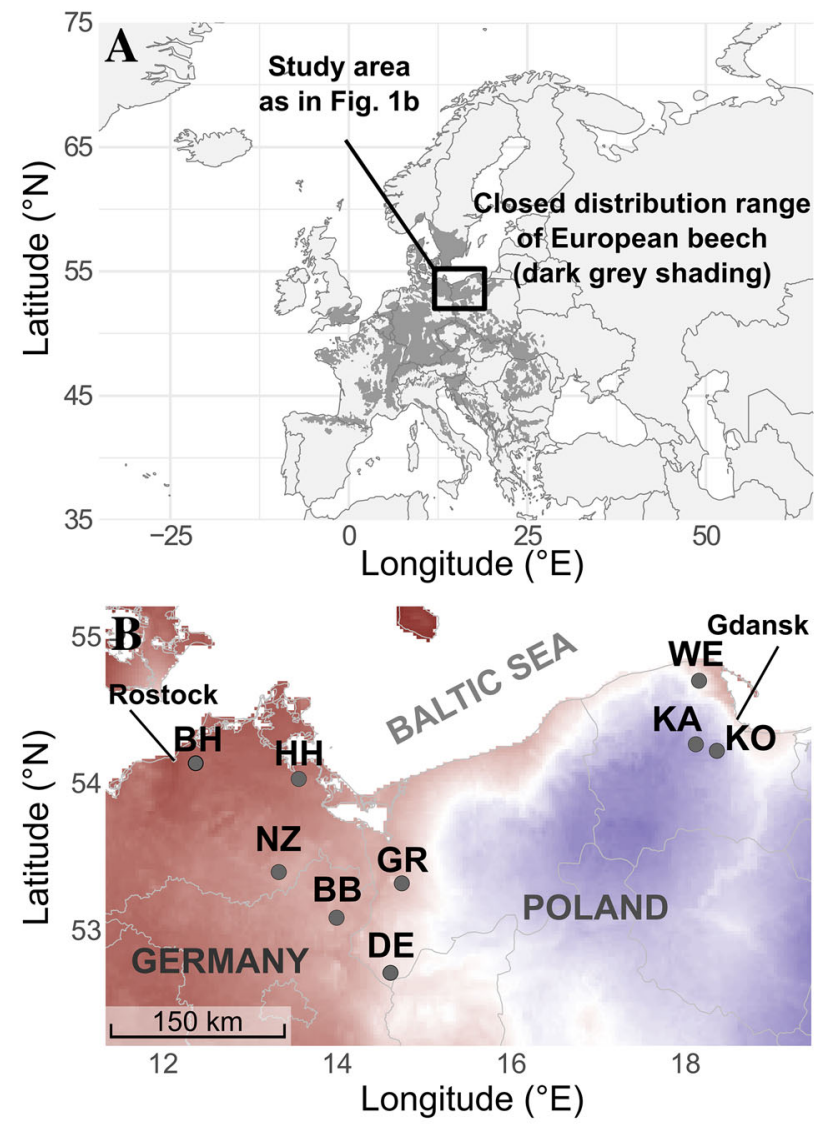

Mean coldest month temperature $\left({ }^{\circ} \mathrm{C}\right)$

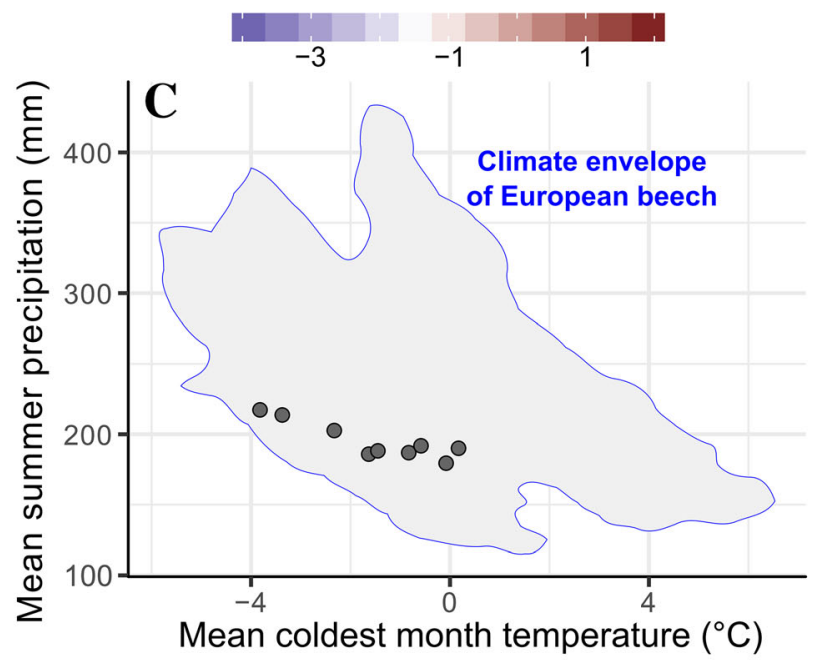

Figure 1. Location of the study area and the experimental sites (gray dots) in Europe (A), along a climatic gradient of decreasing winter air temperature (long-term average "climateEU" data, Hamann and others 2013; Wang and others 2012) between Rostock (Germany) and Gdansk (Poland) (B), and within the climatic distribution range of European beech $(\mathbf{C})$. Climate envelope including 95-percentile of species occurrences data (EUFORGEN 2009) and climate data ("climateEU"; Hamann and others 2013; Wang and others 2012). Map data by South (2011).

precipitation as snow increases from 50 to $110 \mathrm{~mm}$ (water equivalents). Uncorrelated with this spatial trend, total mean winter precipitation ranges 107-
$127 \mathrm{~mm}$ across sites. On average, days with snow cover may occur November-March at all sites and also in April at the three coldest sites (C3S "ERA5- 

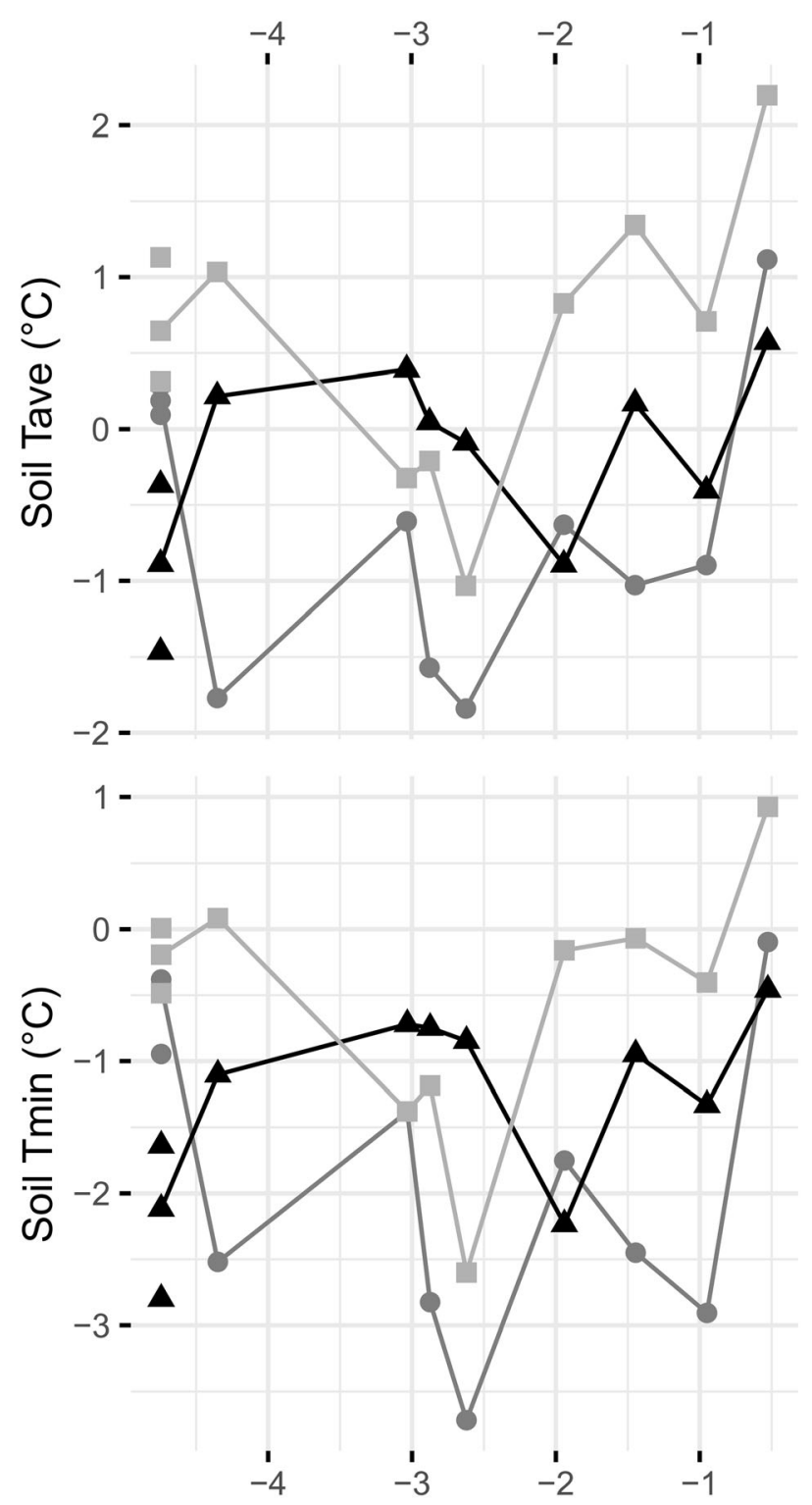

Site mean coldest month temperature $\left({ }^{\circ} \mathrm{C}\right)$

Soil temperature treatment

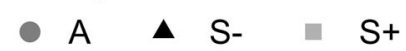

Figure 2. Soil temperature parameters of the experimental plots. $T_{\text {ave }}$ and $T_{\min }$ are the average soil temperature and the absolute minimum soil temperature, respectively, in each experimental plot during the snow manipulation period, November 2016-March 2017 (A: ambient conditions, S-: snow exclusion, S+ : additional soil insulation with fleece blanket). The x-axis represents the long-term average winter air temperature at each site ("climateEU," see Fig. 1).

Land reanalysis," Copernicus Climate Change Service, July 2019, https://cds.climate.copernicus.e $\mathrm{u} / \mathrm{cdsapp} \#$ !/home). At least as indicated from satellite-derived "ERA-5" reanalysis data, average annual maximum snow depth ranges $8-10 \mathrm{~cm}$ across the seven warmest sites and increases markedly toward the two coldest sites (14 to $17 \mathrm{~cm})$. Snow depth varies from year to year, but in analogy to the average snow depth trend, the likelihood of single winters having abnormally low snow depth increases toward the warmer sites (Figure Al in Appendix 1 in the Supplementary material, C3S "ERA5-Land-reanalysis"). The study area is representative of a large part of the winter temperature range of beech, while summer precipitation differences are, in contrast, relatively 
small (Figure 1C). The study area is situated in the Pleistocene lowlands, where the bedrock consists of glacial deposits. All sites have the same soil type (sandy Cambisol) and similar soil texture (mostly sandy silt to silty sand; Table Al in Appendix 1). We further selected the sites to have similar stand structures (tree height 27-39 m, tree diameter 37$52 \mathrm{~cm}$ and canopy closure $70-80 \%$ ). Given the emphasis on identifying sites with uniform stand structure, we accepted differing tree ages across sites (76-167 years), because age is the least important factor determining the physiological constitution and the tree-growth climate relationship compared to tree architecture and tree position within the forest structure (Fritts 1966; Carrer and others 2015; Trouillier and others 2019). At each site, we selected a set of target trees based on a dendroecological pre-study (analysis of tree cores, see Weigel and others 2018) that identified the tree individuals that were most representative of the growing conditions for each site during the last 30 years (three out of 20 at all but the coldest site and nine out of 40 at the coldest site; Figure A2 in Appendix 1). When setting up the experimental plots, each plot was centered on a single target tree.

\section{Experimental Setup and Soil Temperature Manipulation}

Our study was a gradient design field experiment, allowing for improved large-scale generalizability compared to experiments that concentrate all replicates at one or few study sites (De Boeck and others 2015; Kreyling and others 2018). To include as many sites as possible, the replication at each site was limited to three fenced, circular experimental plots of $10 \mathrm{~m}$ in diameter $\left(\sim 80 \mathrm{~m}^{2}\right)$ that featured either ambient conditions (A), snow exclusion (S-) or additional soil insulation (S+), respectively ( $n=1$ of each treatment at each site). The coldest site (KA), however, included a three-fold replication $(n=3)$ of each treatment, because we expected the widest range of soil temperature response to snow manipulation there (later accounted for by including the spatial term "site" in the statistical models). Thus, the whole experiment consisted of 33 plots across the studied temperature gradient. For the $S$ - treatment, snow was blocked from falling to the ground by a transparent plastic cover $(0.2 \mathrm{~mm}$-thick, UV-transmissive "Lumisol clear"; Hermann Meyer KG, Rellingen, Germany) that was mounted on a $1.8 \mathrm{~m}$ high wooden roof frame during the treatment period (November 2016-March 2017). The cover was perforated so that it was permeable to snowmelt water; thus, the treatment received almost the same amount of precipitation, but with a delay. For the $S+$ treatment, soil insulation during winter was increased by a permeable gardening fleece cover $\left(70 \mathrm{~g} / \mathrm{m}^{2}\right.$; Hermann Meyer KG, Rellingen, Germany). In each plot, we measured the soil temperature both at the boundary between the litter layer (O horizon) and topsoil (A horizon), and at a depth of $10 \mathrm{~cm}$ into the topsoil ("TMC20-HD" temperature sensor connected to a "HOBO UX120-006M Analog Data Logger"; Onset Computer Corporation, Bourne, USA) in half-hour intervals. Because of shallow overall frost depth (see Results), we selected the following metrics to describe the treatment effects on soil temperature; (1) the absolute minimum soil temperature (henceforth defined as " $T_{\min }$ ") and (2) the average soil temperature (" $T_{\text {ave }}$ ") during the manipulation period at the shallowest soil temperature measurement depth. We did not use any direct frost indicator (for example, frost degree hours $=$ frost duration $(\mathrm{h}) \mathrm{x}$ frost magnitude $(\mathrm{K}$ below $\left.0{ }^{\circ} \mathrm{C}\right)$ ), because some plots never experienced temperatures below $0{ }^{\circ} \mathrm{C}$ (see Results). Thus, for the statistical analyses, we accounted for the divergent temperature responses in the S- treatment (see Results) by applying regression models with soil temperature as an explanatory variable, instead of applying factorial analysis of variance (see Data analysis).

\section{Ecological and Biogeochemical Response Variables}

After the end of the snow manipulation in spring (March) 2017 when we removed the snow exclusion cover, we measured a suite of ecological and biogeochemical responses. During 2017, measurements were taken in three sampling campaigns that took place, first, in March, before the onset of the growing season, second, late in May, during the early growing season, and third, late in October, after the end of the growing season. In addition, we conducted a sampling campaign during the early growing season in May 2018 (the post-manipulation year) to assess root growth and the sapling establishment rate (see below).

In the following, we briefly introduce all response variables; technical details and a schematic map of a plot are found in Appendix 1 and in Figure A3 in Appendix 1. We assessed aboveground plant responses by measuring the stem increment of the central study tree within each plot (halfhourly point-dendrometer measurements ("DR"; Ecomatik, Munich, Germany) and analog data loggers ("HOBO UX120-006M"; Onset Computer 
Corporation, Bourne, USA)) to derive the onset of stem increment in spring and the total annual stem growth. Annual stem growth in 2017 was measured by the dendrometers as radial increment, which provided a good approximation of basal area increment independent of tree diameter and tree height in our single observation year (Figure A4 in Appendix 1). Further, we measured stem increment and height growth of juvenile beech saplings $(<1 \mathrm{~m}$ height). In addition, we tested beech nut germination rates and beech seedling establishment rates in a germination trial with a standardized set of beech nut provenances (in total 216 beech nuts planted from 18 provenances in three replicates per plot). For assessing potential shortterm responses of the 39 vascular plant species present in the forest understory (Weigel and others 2019), we quantified the temporal species turnover of each plot. We did so by calculating the BrayCurtis dissimilarities between the species composition in spring of the year before the experiment, in spring after the treatment period and in spring of the year after the experiment.

To assess the belowground biotic responses, we estimated the fine root length, fine root growth and main rooting depth of fine roots in the topsoil (top $10 \mathrm{~cm}$ ) of each plot by analyzing 360-degree belowground minirhizotron pictures (three minirhizotrons per plot). Furthermore, we quantified litter decomposition using green tea and red (rooibos) tea bags representing standardized litter material with fast (green tea, similar $\mathrm{C} / \mathrm{N}$ ratio as litter in beech forest topsoil) and slow (red tea, similar $\mathrm{C} / \mathrm{N}$ ratio as fresh beech leaves) decomposition properties due to high and low litter quality, respectively (Vesterdal and others 2008; Keuskamp and others 2013; Cools and others 2014; Djukic and others 2018). From the batch of tea bags initially buried in October 2016, we subsequently excavated two green and two red intact tea bags, respectively, from each plot (averaged to plot mean for green and red tea) at the sample dates described above. We could always discard broken tea bags directly in the field, because we had buried more than enough tea bags. We measured soil respiration rates (mobile infrared gas analyzer LI-820; LICOR, Lincoln, USA) in three subplots per plot in previously (spring 2016) inserted plastic collars $(10 \mathrm{~cm}$ height, $11 \mathrm{~cm}$ diameter) and assessed the soil sensitivity to soil temperature changes by deriving the $\mathrm{Q}_{10}$ temperature coefficient from these soil respiration rates.

We investigated soil nitrogen cycling in three subplots per plot. We used Plant Root Simulator Probes (PRS $\odot$ ion-exchange resin plates; Western
AG, Saskatoon, Canada) that were buried during the soil temperature manipulation in winter (first batch) and for 8 weeks in spring directly after the manipulation (second batch) to obtain temporally integrated estimates of ammonium, nitrate and mineral nitrogen (sum of ammonium and nitrate) available for uptake by plant roots. Additionally, we obtained instantaneous estimates of plant available (mineral) nitrogen in bulk soil samples by extraction of the samples in $2 \mathrm{M} \mathrm{KCl}$, according to Turner and Henry (2010), followed by ion chromatography and UV-absorbance detection. Further, we conducted a ${ }^{15} \mathrm{~N}$ tracer study to assess the treatment effect on the fate of added nitrogen. Directly before setting up the snow manipulation in early November 2016, we injected the nitrogen tracer $\left(27 \mathrm{mg}{ }^{15} \mathrm{~N} / \mathrm{m}^{2}\right.$ as $72.9 \mathrm{mg}{ }^{15} \mathrm{NH}_{4}{ }^{-}{ }^{15} \mathrm{NO}_{3} / \mathrm{m}^{2}$ ) with a syringe and a $4 \mathrm{~cm}$ cannula into the soil. This amount corresponds to only $1.3-2.1 \%$ of the annual airborne nitrogen input per surface area at our study sites (according to gridded nitrogen deposition data "EMEP MSC-W," Simpson and others 2012). After the manipulation, we measured the tracer concentration that was retained over winter as total inorganic plus organic nitrogen $\left({ }^{15} \mathrm{~N}_{\mathrm{tot}}\right)$ in the soil samples. We also determined the ${ }^{15} \mathrm{~N}$ enrichment in the mineral nitrogen adsorbed to the PRS probes to estimate the mineral tracer availability $\left({ }^{15} \mathrm{NH}_{4}{ }^{+}\right.$and $\left.{ }^{15} \mathrm{NO}_{3}{ }^{-}\right)$after concentrating the nitrogen signal by the diffusion method (Schleppi and others 2006; Stephan and Kavanagh 2009, Appendix S1). All the above nitrogen measurements were conducted $10 \mathrm{~cm}$ into the topsoil to investigate nitrogen availability; the measurements were repeated in the subsoil $(50 \mathrm{~cm}$ soil depth) to investigate nitrogen leaching.

\section{Data Analyses}

Treatment effects in gradient design experiments can occur both within and across sites. Thus, we assessed the responses to the soil temperature manipulation treatments by regressing each response variable $(N=33$ plot means for each variable) separately against $T_{\min }$ and $T_{\text {ave }}$ of each plot (Figure 2). We accounted for the confounding effects of the ensemble of all site-specific habitat conditions that may overlay across-site treatment effects by including site as a factorial random effect (random intercept and random slope mixed-effects model). Alternatively, we applied ordinary linear regression modelling including long-term average winter air temperature (mean $T_{\text {ave }}$ ) and soil $\mathrm{pH}_{\mathrm{CaCl} 2}$ as additional covariates to account for these site effects (see Table A2 in Appendix 1). In contrast to 
$T_{\min }, T_{\text {ave }}$ tended to be lower toward colder sites (Figure A5 in Appendix 1), although the manipulation caused strong within-site soil temperature differences (Figure 2B). Very conservatively, we thus only accepted winter soil temperature as significant predictor if mean $T_{\text {ave }}$ (and soil $\mathrm{pH}_{\mathrm{CaCl} 2}$ for responses of nitrogen cycling) did not better explain the observed response after backward elimination of non-significant predictors (final model selection reported in Table A3 in Appendix 1). If necessary, we applied data transformations (Tables A28A3 in Appendix 1) to meet the assumption of normally distributed model residuals (tested with Shapiro-Wilk tests, histograms and quantile-quantile plots) prior to significance testing with a threshold of $p<0.05$. The effect sizes were either quantified by conditional $r^{2}$ (the $r^{2}$ of the fixed effect only, Nakagawa and others 2013) from the linear mixed-effects models or $r^{2}$ from the linear models (pseudo- $r^{2}$ for germination and establishment success as binomial responses according to Nagelkerke 1991). Consequently, the analysis summarizes across our whole study gradient with the reported $r^{2}$ values corresponding to the impact of soil temperature variation while accounting for other site-specific differences. All calculations were conducted in "R" 3.1.1 (R Core Team 2016; see Appendix $\mathrm{l}$ for information on the $\mathrm{R}$ packages used).

We used the random slope coefficients from the mixed-effects modelling in the previous paragraph as indicators for the site-specific sensitivity of responses to soil temperature variation, meaning that steep slopes indicated high sensitivity. Notably, each slope was extracted from the whole-model predictions including all sites and did not only originate from the three observations per site. For the sensitivity analysis across sites, we selected all variables that showed significant responses to the soil temperature manipulation. For each of these selected variables, we regressed the site-specific sensitivities (random slope coefficients) against the climatic gradient (mean $T_{\text {ave }}$ of each site) and we report the resulting $r^{2}$ to quantify the change of sensitivity across the climatic gradient.

\section{RESUlTS}

\section{Soil Abiotic Treatment Effects} and Winter Weather Conditions During the Experiment

Soil moisture after snowmelt did not differ across treatments (gravimetric measurement for topsoil from about $10 \mathrm{~cm}$ depth and for soil at about $50 \mathrm{~cm}$ depth; data not shown). The deeper soil temperature monitoring $(10 \mathrm{~cm}$ into the topsoil) showed that frost did not penetrate to the soil depth of $10 \mathrm{~cm}$ in almost all plots, because temperatures never fell below $0{ }^{\circ} \mathrm{C}$ already at this depth. Any temperature treatment differences disappeared at this depth. Even at the shallowest soil measurement depth, the effect of snow exclusion (S-) was not strong enough to induce soil cooling across all sites (that is, it did not occur at three out of nine sites; Figure 2), and soil cooling due to snow exclusion was most pronounced at the coldest site, which was expected based on there being little to no snowfall toward the warmer end of the gradient. There was also a very weak tendency of the snow out shelters to trap heat, having slightly warmer temperatures below the plastic cover than above $\left(0.04 \pm 0.13{ }^{\circ} \mathrm{C}\right.$, measured during the experiment at site $\mathrm{HH}$ ). Nevertheless, our treatments fulfilled the intended aim to induce gradients of topsoil temperature within each site and across sites, with $\Delta T_{\min }=1-3 \mathrm{~K}$ and $\Delta T_{\text {ave }}=1-1.5 \mathrm{~K}$ (Figure 2). Across all sites, $\Delta T_{\min }$ was $4.5 \mathrm{~K}$ and $\Delta T_{\text {ave }}$ was $3 \mathrm{~K}$. Using $T_{\min }$ as explanatory variable in the statistical analysis proved to be a good substitute for using frost degree hours due to the high correlation of these two variables $\left(r^{2}=0.83\right.$; Figure A5 in Appendix 1). Compared to long-term averages of air temperature and precipitation, the winter 2016/ 2017 in our study area was neither extremely warm $(<1 \mathrm{~K}$ warmer and highly correlated $\left(r^{2}=0.8\right)$ to average winter air temperature across sites), nor extremely dry or wet $(80-125 \%$ of average winter precipitation; according to climate monitoring of Germany's National Meteorological Service, "Deutscher Wetterdienst," www.dwd.de), which becomes also evident in the multi-year comparison of temperature measurements at our sites (Table A4 in Appendix 1).

\section{Responses to Manipulated Soil Temperatures}

The plant growth variables tree stem increment (dendrometer measurements) and fine root length declined by more than a half from the warmest to the coldest end of the realized temperature gradient, beech nut germination success increased by about a third, and rooting depth almost doubled (Figures 3, 4A). All other variables related to above- and belowground plant growth (that is, onset of stem growth of adult trees, sapling height growth and radial increment, root growth rates, seedling establishment and turnover of understory vegetation) were not correlated with winter soil 


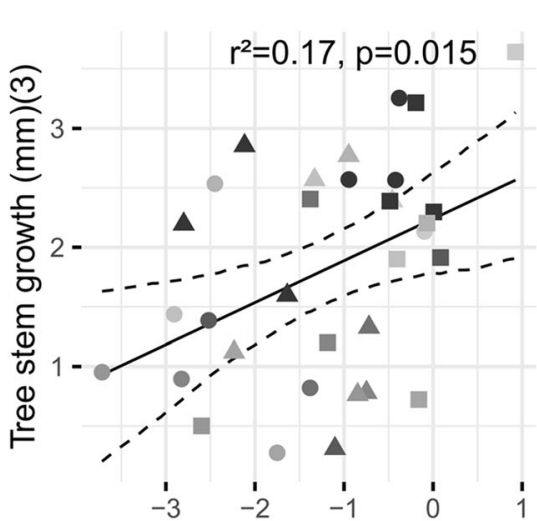

Minimum soil temperature $\left({ }^{\circ} \mathrm{C}\right)$

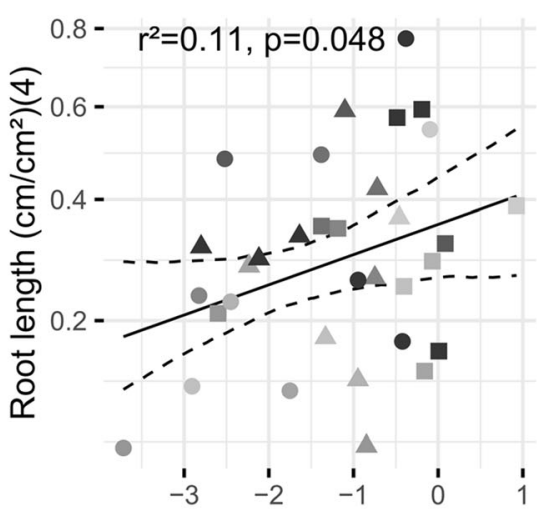

Minimum soil temperature $\left({ }^{\circ} \mathrm{C}\right)$

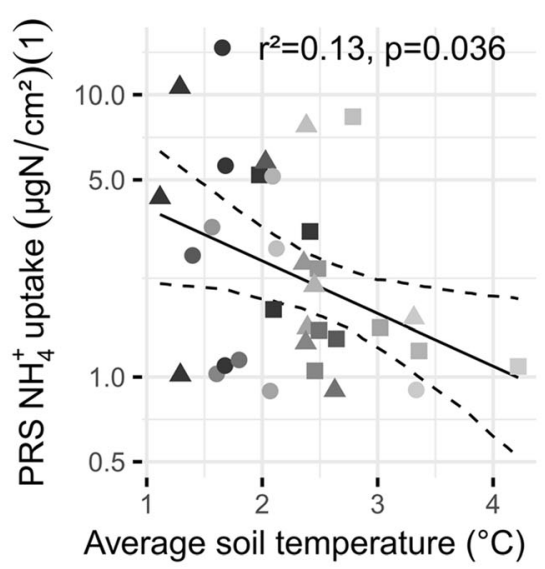

Treatment

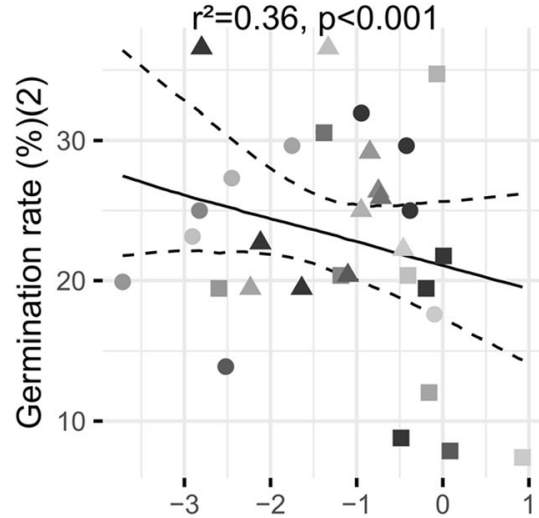

Minimum soil temperature $\left({ }^{\circ} \mathrm{C}\right)$
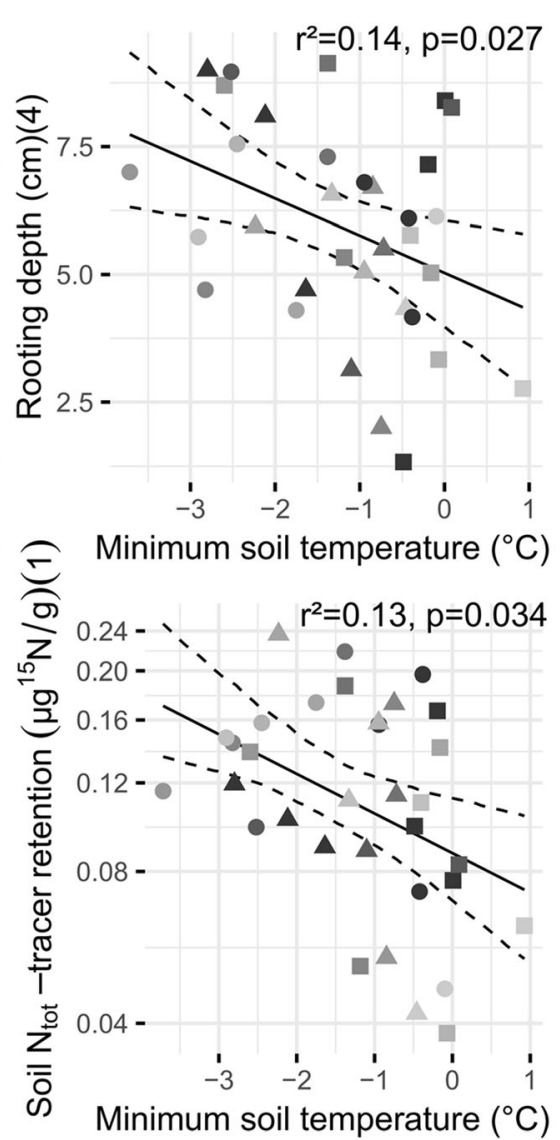

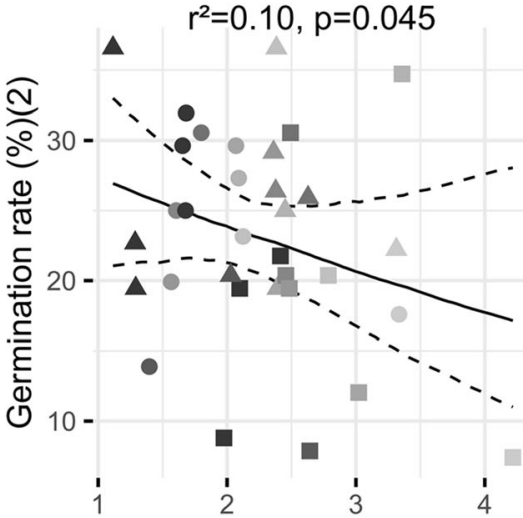

Average soil temperature $\left({ }^{\circ} \mathrm{C}\right)$

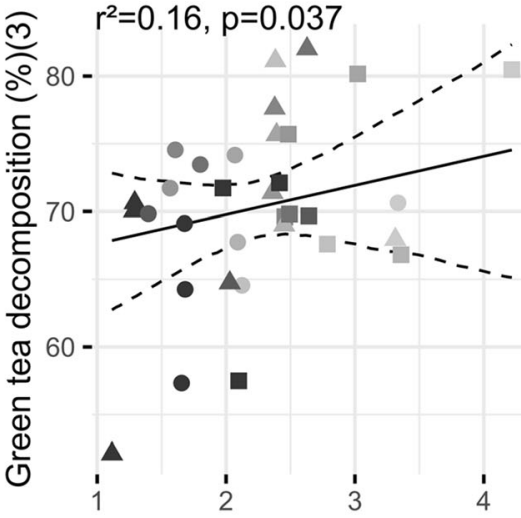

Average soil temperature $\left({ }^{\circ} \mathrm{C}\right)$

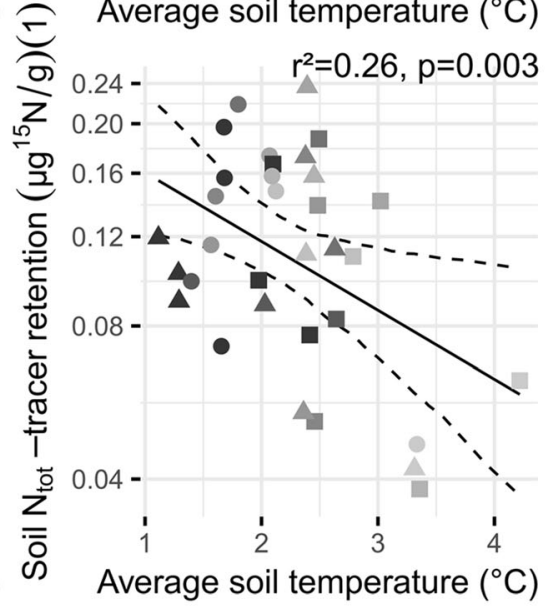

Site (coldest to warmest)

- A $\triangle \mathrm{S}-$ - S +

- $\mathrm{KA} \bullet \mathrm{KO} \bullet \mathrm{WE} \bullet \mathrm{DE} \bullet \mathrm{GR} \bullet \mathrm{BB} \bullet \mathrm{NZ} \bullet \mathrm{HH} \bullet \mathrm{BH}$

Figure 3. Significant responses to soil temperature variation. Regression lines and $r^{2}$ values correspond to the model fixed effects (response to manipulated soil temperature) only, so that variation explained by random effects (spatial term accounting for confounding site effects) is not considered. Dotted lines indicate the $95 \%$ confidence intervals (from 1000 fold bootstrap resampling). For germination success as a binomial process, pseudo- $r^{2}$ values from generalized linear (mixed-effects) modelling are stated. The sampling dates are given in brackets following variable names. The dates (1-3) correspond to sampling before the onset of the growing season (1), during the early growing season (2) and after the end of the growing season (3). (4) corresponds to sampling during the early growing season in the post-manipulation year. 


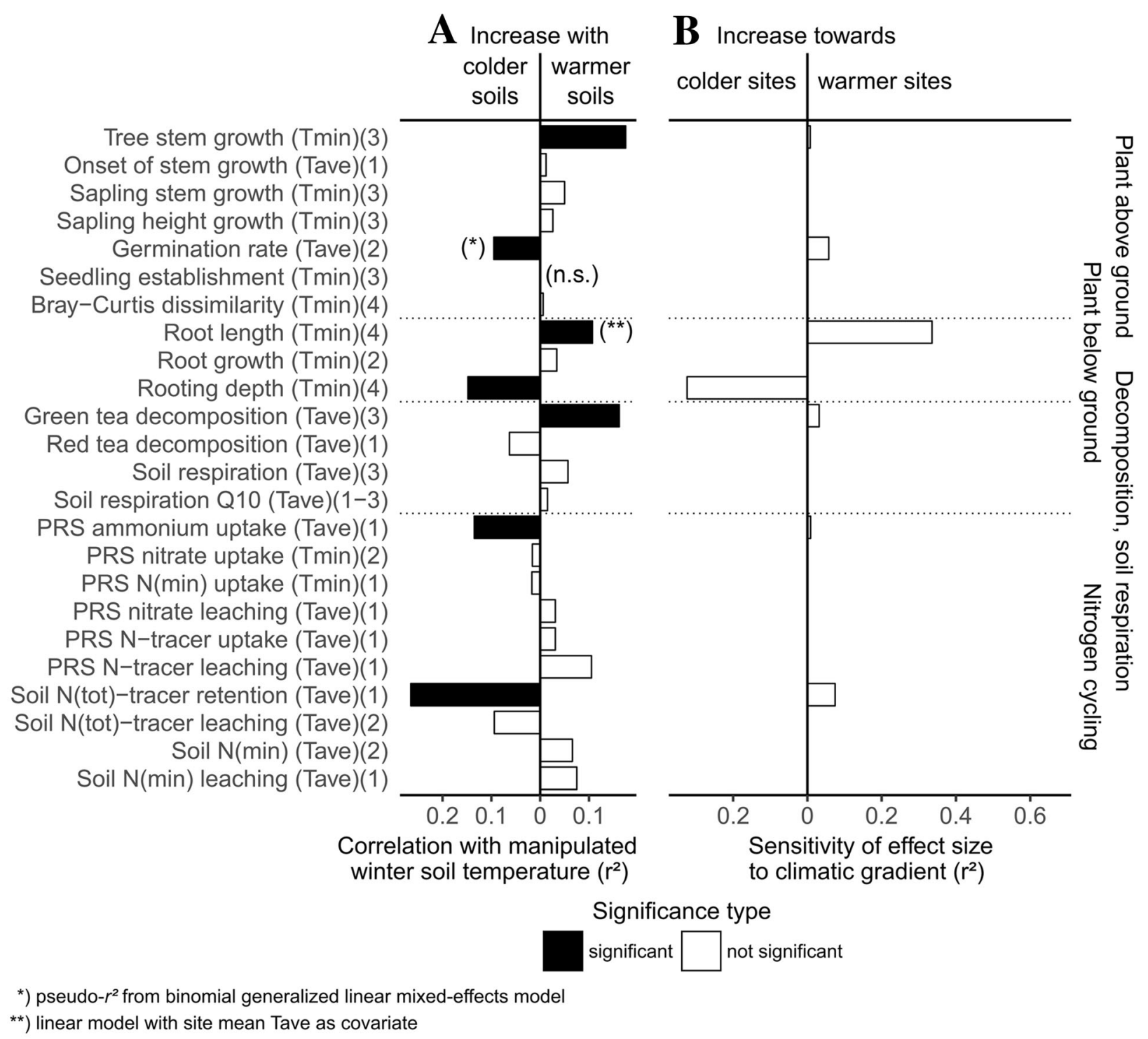

Figure 4. Strongest response of each experimental variable to manipulated soil temperatures (A). The sensitivity of effect sizes to the climatic gradient across sites (B) is expressed as the $r^{2}$ value from regressing the site-specific effect sizes (random slope coefficients of mixed-effects modelling) against the site-specific long-term mean winter air temperature. For each variable, the strongest explanatory variable (absolute minimum soil temperature $T_{\min }$ or average soil temperature $T_{\text {ave }}$ during the manipulation winter) and the sampling date with the strongest response are given in brackets. The dates (1-3) correspond to sampling later in the manipulation year before the onset of the growing season (1), during the early growing season (2) and after the end of the growing season (3). (4) Corresponds to sampling during the early growing season in the post-manipulation year.

temperatures (Figure 4A; also see detailed overview for all response variables regressed against average and minimum soil temperature for all seasons including random slope fits in Figure A6 in the Supplementary material).

Belowground carbon cycling was affected significantly by soil temperature variation, with decomposition rates of easily accessible, highquality material (green tea) by the end of the growing season decreasing with lower winter soil temperature (Figures 3, 4A); over-winter decomposition and the decomposition of material with low litter quality (red tea), however, were not affected significantly by soil temperature variation (Figure 4A).

With respect to nitrogen cycling, the amount of nitrogen tracer $\left({ }^{15} \mathrm{~N}_{\text {tot }}\right)$ retained over winter in the bulk soil increased significantly and the PRS probes 
indicated higher over-winter availability of ammonium with soil cooling (Figures 3, 4A). PRS nitrate and deep-soil nitrogen leaching and growing season tracer retention were not affected significantly by winter soil temperature (Figure 4A).

\section{Site-Specific Sensitivity to Manipulated Soil Temperatures}

The sensitivities of some ecological responses to manipulated soil temperatures differed significantly between sites (that is, significant random slopes deviating from the fixed effect in the mixed-effects modelling; Figure A6). However, the site-specific sensitivity of effect sizes was in no case explained by the local long-term winter conditions (mean $T_{\text {ave }}$ ) across sites (Figure 4B). More precisely, the prevailing winter conditions did not explain the degree of ecological response per degree of soil temperature change.

\section{Discussion}

In northern temperate forests, strong effects of snow manipulation are typically associated with a strong soil freezing effect (for example, Henry 2007; Hosokawa and others 2017; Reinmann and others 2019), which provided the basis of our first hypothesis that soil cooling would decrease plant growth and disrupt biogeochemical cycles. Although only mild and inconsistent soil frost (minimum soil temperatures of -3 to $1{ }^{\circ} \mathrm{C}$ and average winter soil temperatures of 1 to $4{ }^{\circ} \mathrm{C}$ at a soil depth of $<10 \mathrm{~cm}$ ) was induced by snow manipulation due to different natural snow cover conditions across our sites, our results nevertheless demonstrated significant effects of variation in winter soil temperature on plants and soils for a large range of temperate forest sites. Notably, responses to much lower soil temperatures may be studied in colder ecosystems or in artificial laboratory settings, but our findings correspond to previous snow manipulation experiments in Central Europe and represent responses to winter soil temperature variations that are in the realistic range of climate change scenarios in temperate European forests (Henry 2007; Gaul and others 2008; Goldberg and others 2010; Kreyling and Henry 201 1; Kreyling 2020). In our study, germination, litter decomposition and the retention of added ${ }^{15} \mathrm{~N}$ all varied significantly along the induced soil temperature gradient (Figure 4). Winter soil temperatures were correlated significantly with a broader range of plant and soil responses (that is, tree stem increment, root length, rooting depth and soil ammonium availability).
Given that these effects could be confounded by variation in summer climate among sites, the across-site trends might not be due to winter soil temperature variation alone, and they should be evaluated carefully by reference to the whole interacting system of plant growth and soil biogeochemical processes. Nevertheless, we accounted for confounding effects in our analysis, first, by including the study sites as a spatial term (random effect) in the statistical modelling, which may have conservatively lowered the reported $r^{2}$ values compared to "classical" regression analysis without random effects. Second, we accepted winter soil temperatures as explanatory variables only if the mean site conditions (long-term mean of average winter air temperature and soil $\mathrm{pH}$ ) did not better explain the response. Moreover, responses to soil minimum temperature $\left(T_{\min }\right)$ were most likely an independent signal, because $T_{\min }$ was not co-correlated with long-term mean site climate across all seasons (see Figure A5 in Appendix 1).

The sensitivity of response (that is, treatment effect size per degree of soil warming or cooling) was not correlated with variation in mean winter air temperatures among sites (Figure 4), even though the experiment spanned a large winter temperature gradient $(\Delta T=4 \mathrm{~K})$ across $500 \mathrm{~km}$. This result was contrary to our second hypothesis [based on Makoto and others (2014) and Reinmann and others (2019)], which stated that ecosystem responses would be more sensitive to changing winter conditions in the coldest sites, which previously had experienced a history of mild winter soil temperatures due to the presence of continuous snow cover over much of winter. Notably, this hypothesis has not been tested before in a gradient study, and our study presents the first insights about the sensitivity of responses to winter soil temperature variation across several sites.

\section{Soil N Retention Response \\ to Manipulated Soil Temperature in the Context of Tree Growth}

Reductions in tree growth following cold winters typically are explained by frost damage to aboveground plant tissues or by a shortening of the growing season (Dittmar and others 2003; van der Maaten 2012). However, fine root damage from soil frost, and the resulting loss in stored nutrients and the capacity for nutrient uptake, as well as belowground allocation of carbon to sustain compensatory root growth also potentially could reduce stem growth (Pederson and others 2004; Meier and Leuschner 2008; Comerford and others 2013; 
Campbell and others 2014; Sanders-DeMott and others 2018). In our experiment, there was no visible evidence for fine root mortality having increased immediately in response to frost damage based on the fine root biomass estimates from minirhizotron observations (Figure A6). However, it is possible that the moderate soil frosts induced by snow exclusion in European temperate forests increase fine root mortality, while total fine root biomass (dead plus living biomass) remains unaffected (Gaul and others 2008). In contrast to our rough minirhizotron estimates of total fine root biomass, a clear division of the roots into the dead versus living fraction would require a more finescaled ex-situ analysis of the fine root system (Leuschner and others 2001; Gaul and others 2008). Moreover, sub-lethal frost damage to roots that reduces their capacity for nutrient uptake (Malyshev and Henry 2012) may not be detectable from minirhizotron observations. Soil ${ }^{15} \mathrm{~N}$ retention over winter and soil ammonium availability in spring were actually greatest in the plots that featured the lowest soil temperatures (Figure 3). The lack of a nitrate response may have been also due to the much higher plant demand for ammonium during spring in forests (Sanders-DeMott and others 2018). In sum, our results are consistent with decreased microbial processing of mineral nitrogen and a decreased potential for winter and early-spring root $\mathrm{N}$ uptake due to sublethal root cell damage in cold soils (Malyshev and Henry 2012; Comerford and others 2013; SandersDeMott and others 2018).

\section{Forest Rejuvenation and Understory Vegetation}

The germination success of beech seeds (beechnuts) increased with soil cooling over winter (Figures 3,4$)$, but the treatment did not affect seedling establishment, sapling growth, and understory vegetation composition. For germination success, the increases may have resulted from the high cold stratification requirements that initiate germination in beech (Bewley and others 2013; Walck and others 2011). It is difficult to interpret the longerlasting consequences of this improved seed germination in the colder soils, given that seedling establishment in the later sampling dates was not affected by soil temperature manipulation (Figure A6). Moreover, sapling growth did not respond to the manipulation, probably due to complex interactions of various ecological filters that influence the initial and juvenile life stages of trees, apart from winter climate (Jump and others 2006;
Wagner and others 2010). Our experiment did not affect the turnover of the understory species composition, but observable responses of the forest understory composition to changing environmental conditions can lag from years to decades in deciduous temperate forests (Brunet and others 1996).

\section{Variation in Decomposition and Soil Respiration with Soil Temperature Manipulation}

Decreased soil temperature during winter decreased annual decomposition rates (Figures 3,4), which indicates that even mild soil cooling may have affected the decomposer community (Yanai and others 2011). The effect on decomposition rates of high quality litter in particular (green tea as opposed to red tea) contrasts findings from boreal forests, where decomposition of low quality litter was more responsive to decreased winter soil temperature (Bokhorst and others 2013; Kreyling and others 2013). However, temperate and boreal forest floors have different properties and different litter quality, for example, with boreal forest floors generally having a higher $\mathrm{C} / \mathrm{N}$ ratio (Cools and others 2014). The response of green tea decomposition may thus be well representative for the response of beech forest floors, due to their similar litter quality in terms of $\mathrm{C} / \mathrm{N}$ ratio, while being less representative for boreal forest floors (Keuskamp and others 2013; Cools and others 2014). Here, generalizations across ecosystems would benefit from more detailed insights from coordinated network studies (Djukic and others 2018). Despite the decomposition rate response, we did not observe a response of soil respiration to altered soil temperatures (Figure A6). On the one hand, our measurements might have lacked the necessary continuity to capture short-term soil respiration responses in spring to altered winter soil temperatures (Matzner and Borken 2008). On the other hand, reductions in soil temperature can reduce soil respiration by slowing microbial activity (Monson and others 2006). High availability of dead organic material due to frost can fuel overall decomposer activity (Keuper and others 2012; Reinmann and Templer 2018). However, this mechanism was not likely important in our study of winter soil temperature scenarios that are realistic for European temperate regions, where soil frost damage appeared to be minimal, which is in contrast to previous studies reporting stronger responses of the soil compartment, but only under harsh soil temperature treatments (Henry 2007). 
Uniform Sensitivity to Soil Temperature Changes Across the Winter Temperature Gradient

As described above, the sensitivity of responses to altered soil temperatures during winter did not change significantly with variation in long-term mean winter climate along our study gradient (Figure 4), even though the gradient included strong differences in long-term mean winter air temperatures $(\Delta T=4 \mathrm{~K})$. This uniform sensitivity was surprising, given that altered soil temperatures were expected to induce the strongest ecological responses at the coldest sites (Kreyling and Henry 2011; Makoto and others 2014; Reinmann and others 2019), where continuous snow cover historically has resulted in more stable winter soil temperature conditions, and where snow reduction leads to the strongest soil cooling signal (that is, coldest site KA in Figure 2). We argue that our finding is at least representative for our study system of temperate beech forests, because our study ranged from central to cold marginal beech populations. We can only speculate about trends in the sensitivity of responses along even colder study gradients, in which even stronger soil cooling might be simulated by snow removal, because those gradients would be found in completely different forest communities outside the closed distribution range of beech. In addition, the biotic variables we examined responded gradually to the induced soil temperature gradients, which supports the assertion that $0{ }^{\circ} \mathrm{C}$ does not appear to be an important ecological threshold for cold damage in temperate forest ecosystems (Matzner and Borken 2008; Kreyling and Henry 2011). Ecological responses to changing winter soil temperatures may generally occur at abrupt threshold temperatures, for example, during soil freezing or thawing (Schimel and others 2007; Makoto and others 2014; Sanders-DeMott and others 2018), rather than being continuous, but such thresholds were not initiated along our soil temperature gradient. This suggests that such thresholds either may not be ecologically relevant in a study such as ours where extreme frost events were absent or, in contrast, may even lie above $0{ }^{\circ} \mathrm{C}$ (Lennartsson and Ogren 2002; Schimel and others 2007; Kreyling and others 2014).

\section{Outlook: Potential for Diverging Effects of Winter Climate Change Despite Uniform Sensitivity}

Our finding of uniform sensitivity to variation in winter soil temperature across a gradient of Euro- pean beech forests suggests that it is valid to scale up temperature responses in these systems from local studies to regional scales. This upscaling will be facilitated as soon as global databases of modeled soil temperature data, which are currently still under development, will eventually become available (Lembrechts and others 2020). However, this upscaling must account for the anticipated variation in underlying soil temperature scenarios during climate warming among sites. Mirrored by the divergent responses of soil temperature to experimental snow exclusion between the coldest and the rest of our study sites (Figure 2), cold regions with historically high snowfall may experience increasingly harsh soil frost conditions because of increased exposure of soils to cold air during cold snaps (Henry 2008). In warmer regions with historically low snowfall, in contrast, frost exposure may diminish purely due to a decline in the frequency of severely cold air temperatures (Henry 2008; Kreyling and Henry 2011). According to our finding that tree growth decreased with winter minimum soil temperature, which was uncorrelated with air temperature variables and growing season start, winter climate change might decrease tree growth at cold sites (at least when factoring in the effects of changing winter temperatures alone), while it might increase growth at warm sites. Thus, on balance, there may be opposing directions of winter climate change effects along continental gradients of temperate deciduous forests, despite the uniform sensitivity of ecological response.

\section{ACKNOWLEDGEMENTS}

We kindly thank the regional forest management (Forst Brandenburg including the Landeskompetenzzentrum Forst Eberswalde, Landesforst Mecklenburg-Vorpommern, forest management of the University of Greifswald, National Forest Holding of Poland's State Forests in Szczecin, Gdańsk and Toruń) for granting access, assistance with site selection and help during the setup of the experiment and during sampling. We are grateful for the help during field sampling and laboratory analysis by Marta Baba, Isolde Baumann, Hannah Bergmann, Anne Bohm, Annika Behrens, Sascha Bock, Kathrin Bünger, Thea Courtial, Sven Dahlke, Jennifer Gilles, Kai Hobritz, Joachim Hofmann, Alexander Kolb, Fabian Knufinke, Sebastian Lorenz, Ruiping Luo, Hannah Marx, Marie Meininghaus, Ulrich Möbius, Laura Rupenow, Jonas Schmeddes, Simon Wedell and Urszula Wojciechowska. We are very grateful for the great input and thoughts on the initial experimental design 
and on the interpretation of results that we received from Allan Buras, Andrew Reinmann, Marko Smiljanić and Pamela Templer. We also give our special thanks to Alba Anadon-Rosell and Sarah Schwieger for further comments on the manuscript. The study was funded by the DFG (German Research Foundation) with Grant KR 3309/9-1 and by the $D F G$ research training group RESPONSE (RTG 2010). Field work in Poland was also funded by the Forest Research Institute in Poland.

\section{FUNDING}

Open Access funding enabled and organized by Projekt DEAL (Goettingen University).

\section{DATA AVAILABILITY}

Data can be found at: https://doi.org/10.25625/X N7LQY.

\section{Compliance with Ethical Standards}

Conflict of interest The authors declare that they have no conflict of interest.

\section{OPEN ACCESS}

This article is licensed under a Creative Commons Attribution 4.0 International License, which permits use, sharing, adaptation, distribution and reproduction in any medium or format, as long as you give appropriate credit to the original author(s) and the source, provide a link to the Creative Commons licence, and indicate if changes were made. The images or other third party material in this article are included in the article's Creative Commons licence, unless indicated otherwise in a credit line to the material. If material is not included in the article's Creative Commons licence and your intended use is not permitted by statutory regulation or exceeds the permitted use, you will need to obtain permission directly from the copyright holder. To view a copy of this licence, visit $h$ ttp://creativecommons.org/licenses/by/4.0/.

\section{REFERENCES}

Bewley JD, Bradford KJ, Hilhorst HWM, Nonogaki H. 2013. Seeds. New York, NY: Springer. p 399p.

Bokhorst S, Metcalfe DB, Wardle DA. 2013. Reduction in snow depth negatively affects decomposers but impact on decomposition rates is substrate dependent. Soil Biol. Biochem. 62:157-164.
Brown RD, Mote PW. 2009. The response of northern hemisphere snow cover to a changing climate. J. Clim. 22:21242145.

Brunet J, Falkengren-Grerup U, Tyler G. 1996. Herb layer vegetation of south Swedish beech and oak forest-effects of management and soil acidity during one decade. For. Ecol. Manage. 88:259-272.

Bulygina ON, Groisman PY, Razuvaev VN, Radionov VF. 2010. Snow cover basal ice layer changes over Northern Eurasia since 1966. Environ. Res. Lett. 5:15004.

Campbell JL, Socci AM, Templer PH. 2014. Increased nitrogen leaching following soil freezing is due to decreased root uptake in a northern hardwood forest. Glob. Chang. Biol. 20:26632673.

Carrer M, von Arx G, Castagneri D, Petit G. 2015. Distilling allometric and environmental information from time series of conduit size: the standardization issue and its relationship to tree hydraulic architecture. Tree physiol. 35:27-33.

Comerford DP, Schaberg PG, Templer PH, Socci AM, Campbell JL, Wallin KF. 2013. Influence of experimental snow removal on root and canopy physiology of sugar maple trees in a northern hardwood forest. Oecologia 171:261-269.

Cools N, Vesterdal L, de Vos B, Vanguelova E, Hansen K. 2014. Tree species is the major factor explaining C:N ratios in European forest soils. For. Ecol. Manage. 311:3-16.

De Boeck HJ, Vicca S, Roy J, Nijs I, Milcu A, Kreyling J, Jentsch A, Chabbi A, Campioli M, Callaghan T, Beierkuhnlein C, Beier C. 2015. Global change experiments: Challenges and opportunities. BioScience 65:922-931.

Dionne J, Castonguay Y, Nadeau P, Desjardins Y. 2001. Freezing tolerance and carbohydrate changes during cold acclimation of green-type annual bluegrass (Poa annua L.) ecotypes. Crop Science 41:443.

Dittmar C, Zech W, Elling W. 2003. Growth variations of common beech (Fagus sylvatica L.) under different climatic and environmental conditions in Europe-a dendroecological study. For. Ecol. Manage. 173:63-78.

Djukic I, Kepfer-Rojas S, Schmidt IK, Larsen KS, Beier C, Berg B, Verheyen K. 2018. Early stage litter decomposition across biomes. Sci. Total Environ. 628-629:1369-1394.

EUFORGEN. 2009. Distribution map of Beech (Fagus sylvatica). euforgen.org.

Falarz M. 2004. Variability and trends in the duration and depth of snow cover in Poland in the 20th century. Int. J. Climatol. 24:1713-1727.

Fritts HC. 1966. Growth-rings of trees: Their correlation with climate. Science 154:973-979.

Gaul D, Hertel D, Leuschner C. 2008. Effects of experimental soil frost on the fine-root system of mature Norway spruce. J. Plant Nutr. Soil Sci. 171:690-698.

Goldberg SD, Borken W, Gebauer G. 2010. $\mathrm{N}_{2} \mathrm{O}$ emission in a Norway spruce forest due to soil frost: concentration and isotope profiles shed a new light on an old story. Biogeochemistry 97:21-30.

Groffman PM, Driscoll CT, Fahey TJ, Hardy JP, Fitzhugh RD, Tierney GL. 2001. Colder soils in a warmer world: A snow manipulation study in a northern hardwood forest ecosystem. Biogeochemistry 56:135-150.

Hamann A, Wang T, Spittlehouse DL, Murdock TQ. 2013. A comprehensive, high-resolution database of historical and projected climate surfaces for western North America. Bull. Amer. Meteor. Soc. 94:1307-1309. 
Hawkins BJ, Guest HJ, Kolotelo D. 2003. Freezing tolerance of conifer seeds and germinants. Tree Physiol. 23:1237-1246.

Henry HAL. 2007. Soil freeze-thaw cycle experiments: Trends, methodological weaknesses and suggested improvements. Soil Biol. Biochem. 39:977-986.

Henry HAL. 2008. Climate change and soil freezing dynamics. Historical trends and projected changes. Clim. Chang. 87:421434.

Hosokawa N, Isobe K, Urakawa R, Tateno R, Fukuzawa K, Watanabe T, Shibata H. 2017. Soil freeze-thaw with root litter alters $\mathrm{N}$ transformations during the dormant season in soils under two temperate forests in northern Japan. Soil Biol. Biochem. 114:270-278.

Iijima Y, Fedorov AN, Park H, Suzuki K, Yabuki H, Maximov TC, Ohata T. 2010. Abrupt increases in soil temperatures following increased precipitation in a permafrost region, central Lena River basin. Russia. Permafrost and Periglacial Processes $21(1): 30-41$.

IPCC. 2013. Climate Change 2013: The Physical Science Basis. Contribution of Working Group I to the Fifth Assessment Report of the Intergovern- mental Panel on Climate Change [Stocker, T.F., D. Qin, G.-K. Plattner, M. Tignor, S.K. Allen, J. Boschung, A. Nauels, Y. Xia, V. Bex and P.M. Midgley (eds.)]. Cambridge University Press, Cambridge, United Kingdom and New York, NY, USA, 1535 pp.

Jump AS, Hunt JM, Martínez-Izquierdo JA, Peñuelas J. 2006. Natural selection and climate change: temperature-linked spatial and temporal trends in gene frequency in Fagus sylvatica. Mol. Ecol. 15:3469-3480.

Jyske T, Manner M, Mäkinen H, Nöjd P, Peltola H, Repo T. 2012. The effects of artificial soil frost on cambial activity and xylem formation in Norway spruce. Trees 26:405-419.

Keuper F, Bodegom PM, Dorrepaal E, Weedon JT, Hal J, Logtestijn RSP, Aerts R. 2012. A frozen feast. Thawing permafrost increases plant-available nitrogen in subarctic peatlands. Glob. Chang. Biol. 18:1998-2007.

Keuskamp JA, Dingemans BJJ, Lehtinen T, Sarneel JM, Hefting MM, Muller-Landau H. 2013. Tea Bag Index. A novel approach to collect uniform decomposition data across ecosystems. Methods Ecol. Evol. 4:1070-1075.

Kreyling J. 2020. The ecological importance of winter in temperate, boreal, and arctic ecosystems in times of climate change. Cánovas FM, Lüttge U, Leuschner C, Risueño M-C, editors. Progress in Botany Vol. 81. Cham, Switzerland: Springer. p377-399.

Kreyling J, Buhk C, Backhaus S, Hallinger M, Huber G, Huber L, Jentsch A, Konnert M, Thiel D, Wilmking M, Beierkuhnlein C. 2014. Local adaptations to frost in marginal and central populations of the dominant forest tree Fagus sylvatica L. as affected by temperature and extreme drought in common garden experiments. Ecol. Evol. 4:594-605.

Kreyling J, Haei M, Laudon H. 2012. Absence of snow cover reduces understory plant cover and alters plant community composition in boreal forests. Oecologia 168:577-587.

Kreyling J, Haei M, Laudon H. 2013. Snow removal reduces annual cellulose decomposition in a riparian boreal forest. Can. J. Soil. Sci. 93:427-433.

Kreyling J, Henry HAL. 2011. Vanishing winters in Germany. Soil frost dynamics and snow cover trends, and ecological implications. Clim. Res. 46:269-276.

Kreyling J, Schweiger AH, Bahn M, Ineson P, Migliavacca M, Morel-Journel T, Christiansen JR, Schtickzelle N, Larsen KS.
2018. To replicate, or not to replicate - that is the question: how to tackle nonlinear responses in ecological experiments. Lett: Ecol.

Lembrechts JJ, Aalto J, Ashcroft MB, de Frenne P, Kopecký M, Lenoir J, Luoto M, Maclean IMD, Roupsard O, Fuentes-Lillo E, García RA, Pellissier L, Pitteloud C, Alatalo JM, Smith SW, Björk RG, Muffler L, Cesarz S, Gottschall F, Backes AR, Okello J, Urban J, Plichta R, Svátek M, Phartyal SS, Wipf S, Eisenhauer N, Puşcaş M, Dan Turtureanu P, Varlagin A, Dimarco RD, Jump AS, Randall K, Dorrepaal E, Larson K, Walz J, Vitale L, Svoboda M, Finger Higgens R, Halbritter AH, Curasi SR, Klupar I, Koontz A, Pearse WD, Simpson E, Stemkovski M, Graae BJ, Vedel Sørensen M, Høye TT, Fernández Calzado MR, Lorite J, Carbognani M, Tomaselli M, Forte T'aGW, Petraglia A, Haesen S, Somers B, van Meerbeek K, Björkman MP, Hylander K, Merinero S, Gharun M, Buchmann N, Dolezal J, Matula R, Thomas AD, Bailey JJ, Ghosn D, Kazakis G, Pablo MA de, Kemppinen J, Niittynen P, Rew L, Seipel T, Larson C, Speed JDM, Ardö J, Cannone N, Guglielmin M, Malfasi F, Bader MY, Canessa R, Stanisci A, Kreyling J, Schmeddes J, Teuber L, Aschero V, Čiliak M, Máliš F, Smedt P de, Govaert S, Meeussen C, Vangansbeke P, Gigauri K, Lamprecht A, Pauli H, Steinbauer K, Winkler M, Ueyama M, Nuñez MA, Ursu T-M, Haider S, Wedegärtner REM, Smiljanic $M$, Trouillier $M$, Wilmking M, Altman J, Brůna J, Hederová L, Macek M, Man M, Wild J, Vittoz P, Pärtel M, Barančok P, Kanka R, Kollár J, Palaj A, Barros A, Mazzolari AC, Bauters M, Boeckx P, Benito Alonso JL, Zong S, Di Cecco V, Sitková Z, Tielbörger K, van den Brink L, Weigel R, Homeier J, Dahlberg CJ, Medinets S, Medinets V, Boeck HJ de, Portillo-Estrada M, Verryckt LT, Milbau A, Daskalova GN, Thomas HJD, Myers-Smith IH, Blonder B, Stephan JG, Descombes P, Zellweger F, Frei ER, Heinesch B, Andrews C, Dick J, Siebicke L, Rocha A, Senior RA, Rixen C, Jimenez JJ, Boike J, Pauchard A, Scholten T, Scheffers B, Klinges D, Basham EW, Zhang J, Zhang Z, Géron C, Fazlioglu F, Candan O, Sallo Bravo J, Hrbacek F, Laska K, Cremonese E, Haase P, Moyano FE, Rossi C, Nijs I. 2020. SoilTemp: a global database of near-surface temperature. Glob. Chang. Biol.

Lennartsson M, Ogren E. 2002. Causes of variation in cold hardiness among fast-growing willows (Salix spp.) with particular reference to their inherent rates of cold hardening. Plant Cell. Environ. 25:1279-1288.

Leuschner C, Hertel D, Coners H, Büttner V. 2001. Root competition between beech and oak: a hypothesis. Oecologia 126:276-284.

Leuschner C, Meier IC, Hertel D. 2006. On the niche breadth of Fagus sylvatica. Soil nutrient status in 50 Central European beech stands on a broad range of bedrock types. Ann. For. Sci. 63:355-368.

Mabry CM, Gerken ME, Thompson JR. 2007. Seasonal storage of nutrients by perennial herbaceous species in undisturbed and disturbed deciduous hardwood forests. Appl. Veg. Sci. 11:3744.

Makoto K, Kajimoto T, Koyama L, Kudo G, Shibata H, Yanai Y, Cornelissen JHC. 2014. Winter climate change in plant-soil systems. Summary of recent findings and future perspectives. Ecol. Res. 29:593-606.

Malyshev AV, Henry HAL. 2012. N uptake and growth responses to sub-lethal freezing in the grass Poa pratensis L. Plant Soil 360:175-185.

Matzner E, Borken W. 2008. Do freeze-thaw events enhance C and $\mathrm{N}$ losses from soils of different ecosystems? A review. Eur. J. Soil Sci. 59:274-284. 
McCabe GJ, Wolock DM. 2010. Long-term variability in Northern Hemisphere snow cover and associations with warmer winters. Clim. Chang. 99:141-153.

Meier IC, Leuschner C. 2008. Belowground drought response of European beech: Fine root biomass and carbon partitioning in 14 mature stands across a precipitation gradient. Glob. Chang. Biol. 14:2081-2095.

Monson RK, Lipson DL, Burns SP, Turnipseed AA, Delany AC, Williams MW, Schmidt SK. 2006. Winter forest soil respiration controlled by climate and microbial community composition. Nature 439:711-714.

Nagelkerke NJD. 1991. A note on a general definition of the coefficient of determination. Biometrika 78:691-692.

Nakagawa S, Schielzeth H, O'Hara RB. 2013. A general and simple method for obtaining $\mathrm{R}^{2}$ from generalized linear mixed-effects models. Methods Ecol. Evol. 4:133-142.

Pederson N, Cook ER, Jacoby GC, Peteet DM, Griffin KL. 2004. The influence of winter temperatures on the annual radial growth of six northern range margin tree species. Dendrochronologia 22:7-29.

Petoukhov V, Semenov VA. 2010. A link between reduced Barents-Kara sea ice and cold winter extremes over northern continents. J. Geophys. Res. 115:D21111.

R Core Team. 2016. R: A Language and Environment for Statistical Computing. Vienna: Austria.

Reinmann AB, Susser JR, Demaria EMC, Templer PH. 2019. Declines in northern forest tree growth following snowpack decline and soil freezing. Glob. Chang. Biol. 25:420-430.

Reinmann AB, Templer PH. 2016. Reduced winter snowpack and greater soil frost reduce live root biomass and stimulate radial growth and stem respiration of red maple (Acer rubrum) trees in a mixed-hardwood forest. Ecosystems 19:129-141.

Reinmann AB, Templer PH. 2018. Increased soil respiration in response to experimentally reduced snow cover and increased soil freezing in a temperate deciduous forest. Biogeochemistry 66:317.

Sanders-DeMott R, Sorensen PO, Reinmann AB, Templer PH. 2018. Growing season warming and winter freeze-thaw cycles reduce root nitrogen uptake capacity and increase soil solution nitrogen in a northern forest ecosystem. Biogeochemistry 137:337-349.

Schimel J, Balser TC, Wallenstein M. 2007. Microbial stress-response physiology and its implications for ecosystem function. Ecology 88:1386-1394.

Schleppi P, Bucher-Wallin I, Saurer M, Jäggi M, Landolt W. 2006. Citric acid traps to replace sulphuric acid in the ammonia diffusion of dilute water samples for ${ }^{15} \mathrm{~N}$ analysis. Rapid Commun. Mass Spectrom. 20:629-634.

Schuerings J, Beierkuhnlein C, Grant K, Jentsch A, Malyshev A, Peñuelas J, Sardans J, Kreyling J. 2013. Absence of soil frost affects plant-soil interactions in temperate grasslands. Plant Soil 371:559-572.

Schuerings J, Jentsch A, Walter J, Kreyling J. 2014. Winter warming pulses differently affect plant performance in temperate heathland and grassland communities. Ecol. Res. 29:561-570.

Simpson D, Benedictow A, Berge H, Bergström R, Emberson LD, Fagerli $\mathrm{H}$, Flechard CR, Hayman GD, Gauss M, Jonson JE, Jenkin ME, Nyíri A, Richter C, Semeena VS, Tsyro S, Tuovinen J-P, Valdebenito Á, Wind P. 2012. The EMEP MSC-W chemical transport model - technical description. Atmos. Chem. Phys. 12:7825-7865.
South A. 2011 . rworldmap: A new R package for mapping global data. The R Journal 3:35-43. http://journal.r-project.org/arch ive/2011-1/RJournal_2011-1_South.pdf.

Stephan K, Kavanagh KL. 2009. Suitability of the diffusion method for natural abundance nitrogen-15 analysis. Soil Sci. Soc. Am. J. 73:293.

Sturm M, Holmgren J, König M, Morris K. 1997. The thermal conductivity of seasonal snow. J. Glaciol. 43:26-41.

Suvanto S, Henttonen HM, Nöjd P, Helama S, Repo T, Timonen M, Mäkinen H. 2017. Connecting potential frost damage events identified from meteorological records to radial growth variation in Norway spruce and Scots pine. Trees 31:20232034.

Trouillier M, van der Maaten-Theunissen M, Scharnweber T, Würth D, Burger A, Schnittler M, Wilmking M. 2019. Size matters-a comparison of three methods to assess age- and size-dependent climate sensitivity of trees. Trees 33:183-192.

Turner MM, Henry HAL. 2010. Net nitrogen mineralization and leaching in response to warming and nitrogen deposition in a temperate old field: the importance of winter temperature. Oecologia 162:227-236.

van der Maaten E. 2012. Climate sensitivity of radial growth in European beech (Fagus sylvatica L.) at different aspects in southwestern Germany. Trees 26:777-788.

Vesterdal L, Schmidt IK, Callesen I, Nilsson LO, Gundersen P. 2008. Carbon and nitrogen in forest floor and mineral soil under six common European tree species. For. Ecol. Manage. 255:35-48.

Wagner S, Collet C, Madsen P, Nakashizuka T, Nyland RD, Sagheb-Talebi K. 2010. Beech regeneration research. From ecological to silvicultural aspects. For. Ecol. Manage. 259:2172-2182.

Walck JL, Hidayati SN, Dixon KW, Thompson KEN, Poschlod P. 2011. Climate change and plant regeneration from seed. Glob. Chang. Biol. 17:2145-2161.

Wang T, Hamann A, Spittlehouse DL, Murdock TQ. 2012. ClimateWNA-high-resolution spatial climate data for Western North America. J. Appl. Meteor. Climatol. 51:16-29.

Weigel R, Gilles J, Klisz M, Manthey M, Kreyling J. 2019. Forest understory vegetation is more related to soil than to climate towards the cold distribution margin of European beech. J. Veg. Sci. 30:746-755.

Weigel R, Muffler L, Klisz M, Kreyling J, van der Maaten-Theunissen M, Wilmking M, van der Maaten E. 2018. Winter matters: Sensitivity to winter climate and cold events increases towards the cold distribution margin of European beech (Fagus sylvatica L.). J. Biogeogr. 45:2779-2790.

Wipf S, Stoeckli V, Bebi P. 2009. Winter climate change in alpine tundra. Plant responses to changes in snow depth and snowmelt timing. Clim. Chang. 94:105-121.

Yanai Y, Toyota K, Okazaki M. 2011. Effects of successive soil freeze-thaw cycles on soil microbial biomass and organic matter decomposition potential of soils. Soil Sci. Plant Nutr. 50:821-829.

Yang S, Christensen JH. 2012. Arctic sea ice reduction and European cold winters in CMIP5 climate change experiments. Geophys. Res. Lett. 39:890.

Ye K, Lau N-C. 2017. Influences of surface air temperature and atmospheric circulation on winter snow cover variability over Europe. Int. J. Climatol. 37:2606-2619. 